\title{
A Perspective to Combat Covid-19 Disease: Manufacturing and Formulating Inhalable Pharmaceuticals
}

\author{
Amilia Firman Kurniawansyah ${ }^{1 *}$, Agung Kridoyono ${ }^{2}$ \\ ${ }^{I}$ Department of Chemical Engineering, Institut Teknologi Sepuluh Nopember, Surabaya, Indonesia \\ ${ }^{2}$ Department of Informatics Universitas 17 Agustus 1945, Surabaya, Indonesia \\ *Corresponding author.Email: fkurniawansyah14@gmail.com
}

\begin{abstract}
Since its break out in 2019, the Covid - 19 pandemic has affected many aspects of life. The viral disease even endangers human civilization due to the highly virulent and fatality of its effect. The virus has been known to disturb human pulmonary system through cytokine storm occurrence. The pulmonary system, other than being the entrance of the disease has also been known for its potential of direct systemic treatment for many illnesses. Thus, the lungs provide opportunity to retaliate the disease virus infections. This short article is written to overlook possibility to combat the disease through pulmonary administration strategy. The focus of the article will be on existing technology to produce particles suitable for this application. Experience from treatment of other diseases prior to the emergence of this pandemic could be useful to exploit, for future patients treatment.
\end{abstract}

\section{Keywords: Covid-19, inhale, droplets, pulmonary administration strategy}

\section{INTRODUCTION}

The world is currently facing one of the largest pandemic human civilization have ever had; the corona virus -19 (Covid - 19). The first outbreak of the virus was detected in December 2019, in Wuhan, China and by March 2020 it has been declared as global pandemic by the World Health Organization (WHO). Since then, according to the WHO - website per 13 July 2021, Covid 19 has spread to more than 215 countries, infected more than 180 million people and brought approximately 4 million fatalities.

Covid -19 , or the severe acute respiratory syndrome coronavirus - 2 (SARS CoV -2), is one of the seven corona-viruses existing in the world. Having crown - like spikes in its form, Covid - 19, has been considered closely related to its predecessors: SARS $-\mathrm{CoV}$ and MERS (Middle - East respiratory syndrome coronavirus). Scientists categorize those three corona-viruses as harmful since they tend to induce severe health problems, even deaths [1].

Typical pathology pattern of Covid - 19 upon infection is rapid multiplication of the viruses, followed by cytokine storm resulted from excessive immune response. The Covid - 19 causes inflammatory pulmonary response, and as the disease progresses, it affects alveoli and eventually disturb pulmonary functions which lead to deaths [2].

The fact that Covid - 19 primary action is in the human pulmonary region can be considered intriguing. Human pulmonary pathway is a vital organ in which traffic of gaseous exchange occurs. When this area is under attack by pathogenic causes, a systemic disorder, or even fatalities may result. However, human pulmonary track also provides several advantages for an effective therapeutical treatment. As reported in numerous scientific documents, pulmonary pathway can be exploited for alternative pharmaceutical administrations. Large surface area in the lungs, at least $100 \mathrm{~m}^{2}$, with thin absorptive mucosal membrane $(0.1-0.2 \mathrm{~mm})$ is a potential place to induce local and systemic therapy, overcoming difficulties exist in other form of administrations such as the popular oral strategy $[3,4]$.

The success to employ pulmonary strategy lies in the capability to select potential therapeutics along with formulation and delivery strategy. In addition, processing particles suitable for this administration plays a pivotal role to achieve efficient treatment. By far, no drugs have been approved by authorities to cure Covid -19 . Scientists are still seeking appropriate pharmaceuticals to treat patients. They also have been trying several strategies such 
as drug repositioning which has been adapted from experience to combat asthma and other pulmonary related diseases. While several pharmaceuticals are under investigations, scientists have been attempting to study particle formulation and engineering. Implementation of both strategies, combined with vaccine development in particular, is expected to accelerate the end of this prolonged pandemic.

This article is a preliminary stage to develop pulmonary strategy to fight Covid -19 . The discussion focuses on available technology, which can be used to prepare anti-Covid - 19 potential candidates as inhalable formulations. The article will also highlight several potential pharmaceuticals and nutraceutical that might be used for Covid - 19 treatments.

\section{ENGINEERING APPROACH}

The methodology discussed the method of data collection by reviewing on the previous studies on the challenges faced in managing pandemic COVID-19. The source used for this paper is secondary data. The secondary data is the data collected by a party that has nothing to do with the investigation but has collected it for any other purpose at a different time in the past. The secondary data is collected from journals, articles, other printed material and so forth. These data were significant as a support to strengthen the decision. The purpose of collecting data through this technique is to determine the challenges faced in managing COVID-19 pandemic in Malaysia.

Apart from its function as gaseous exchange region, lungs' epithelium enables inhaled substances to enter blood circulatory system. However, in order to achieve the lower region of the lungs, in which absorption primarily occurs, particles should be able to pass through natural barrier in the system, flowing along the air stream. Engineering approach becomes critical to ensure bioactive or pharmaceuticals to deposit in the pulmonary system.

\subsection{Droplet Instrument}

An important factor in pulmonary delivery is the selection of devices which are responsible to create droplets and deliver them into particular site in the lungs. There are three most popular types of devices available in practice: nebulizer, metered-dose and dry - powder inhalers [5].

Each type has its own characteristics depending on the drug and formulations used. The nebulizer is the simplest to operate, but it needs a compressor as a facilitating instrument which adds to its investment and operational costs. The metered - dose inhaler, or the MDI, has been popular as it may deliver aerosolized mists to the lungs. However, the MDI design is relatively complex, involving several supporting instruments and excipients. The dry powder inhaler (DPI) has been proposed to circumvent several drawbacks commonly appear in the MDI. In the DPI, bioactives (therapeutic agents) is mixed with carriers to form specific formula. The particles of composite pharmaceuticals are delivered to the lungs in form of solid samples. Compared to the MDI, the DPI, in general, has higher effectiveness in delivering particles to the designated location. The DPI may deliver up to $30 \%$ of drug particles, more effective than the MDI which sets a record of $15 \%$ of effectiveness [4]. Detail of the device principle design and operation can be consulted elsewhere in the literatures [6,7]. Table 1 is a summary of the devices features comparison.

Table 1. Comparison of droplet devices: nebulizers, metered dose and dry powder inhalers $[8,9,10]$

\begin{tabular}{|c|c|c|}
\hline Device & Advantages & Disadvantages \\
\hline Nebulizers & $\begin{array}{l}\text { - Simple to use } \\
\text { - No propellant } \\
\text { - Small residual } \\
\text { volume }\end{array}$ & $\begin{array}{l}\text { - Difficult to con- } \\
\text { trol doses } \\
\text { - Temperature in- } \\
\text { crease } \\
\text { - Complex instal- } \\
\text { lation }\end{array}$ \\
\hline $\begin{array}{l}\text { Metered } \\
\text { Dose Inhaler } \\
(\mathrm{MDI})\end{array}$ & $\begin{array}{l}\text { - Small, porta- } \\
\text { ble } \\
\text { - Moderate ef- } \\
\text { fectiveness }\end{array}$ & $\begin{array}{l}\text { - Use of propel- } \\
\text { lant } \\
\text { - Complex design }\end{array}$ \\
\hline $\begin{array}{l}\text { Dry Powder } \\
\text { Inhaler (DPI) }\end{array}$ & $\begin{array}{l}\text { - Easy to use } \\
\text { - Breath actu- } \\
\text { ated }\end{array}$ & $\begin{array}{l}\text { - High inspiratory } \\
\text { flow required } \\
\text { (low compliance } \\
\text { with children) }\end{array}$ \\
\hline
\end{tabular}

\subsection{Particle Technology}

Particle suitable for pulmonary administration should meet several criteria. The first is particle size range should fall between $1-5 \mu \mathrm{m}$. Second, particle should be in elongated dimension and covered with carrier, usually from sugar compounds. The next is particle is expected to be inhalable, to have at least $20 \%$ of it can reach lower part of human lung. The term of inhalable is represented by a parameter called the fine particle fraction or the FPF [11]. With these properties, particles can be considered to have potential in pulmonary applications.

Producing particles within pulmonary criteria can be attempted by several strategies. Formulation has been a pivotal factor since it facilitates bioactive delivery in the appropriate sites. Excipients such as polymers have 
been frequently used to modify bioactive particle designed for this applications. Due to their efficacy and safety, lactose, mannitol and glucose have been the most popular excipients applied. Further those three sugars are licensed by drug authorities such as the Food and Drug Administration (FDA) to be used in human pulmonary applications [5].

Complemented with formulation, particle production technology has been essential to produce pulmonary powders. Skill to explore mass transfer, heat transfer, fluid dynamics and phase equilibrium is critical to obtain successful manufacturing. Techniques to produce pulmonary particles have been embodied in various methods. Several popular technologies have been the spray drying, freeze drying, solvent precipitation and supercritical methods. Each method has its own advantages and drawbacks [12].

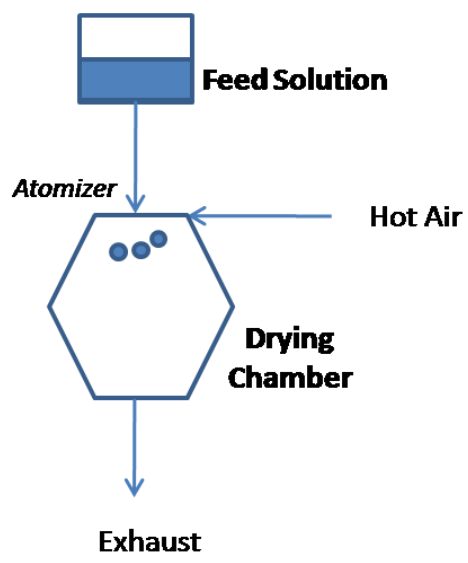

(a)

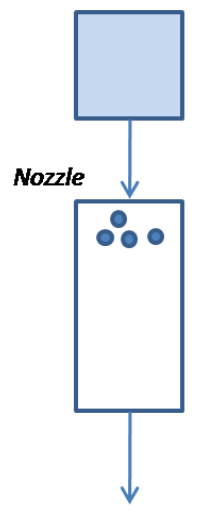

Dissolved

Solid in SCF

Exhaust

(b)

Figure 1. Schematic diagram of (a) spray drying and (b) supercritical based (rapid expansion of supercritical solutions - RESS) methods
The spray drying may be the most popular due to its wide compatibility applications. However, this method suffers drawbacks from low aqueous solubility of feed material which poses a challenge for increased capacity production. The freeze drying has been effective to produce particles, but it is a relatively expensive technology to implement. Similarly, the supercritical fluid based method has been explored due to its versatility, though it has pitfalls on expensive instrumentation to meet safety criteria. The solvent evaporation method could be used to prepare particles with controlled particle size distribution. However, this method is producing waste of organic solvent as a downside, in addition to its tedious processing steps. Thus it has been common to combine the methods with commination or attrition method such as milling to refine the existing technology $[12,13]$. Other techniques have also been attempted such as nanotechnology - based, solvent evaporation and particle replication methods. However, their applications have been investigated mainly in laboratory scales.

\section{THERAPEUTIC CANDIDATES}

Attempts in finding appropriate therapeutic agents have been conducted since the pandemic broke out. A few names such as dexamethasone (corticosteroid antiinflammatory), redemsivir (anti-viral), ivermectin (antiparasitic) and phytochemicals (such as curcumin) have been investigated as drug candidates. However the results by far have been inconclusive. Table 2 is a short list of several pharmaceuticals investigated in this particular case.

One thing commonly found in the proposed drug investigation is suggestion to explore alternatives, particularly in the administration and formulations. Scholars recommends for thorough investigation on intravenous and pulmonary deliveries. Both administration strategies have been considered effective due to their more direct delivery modes and systemic effects. In particular the pulmonary pathway would be potential in the long term if the pandemic becomes seasonal disease.

However, indeed, the development of alternative strategy such as pulmonary pathway exploration would be meaningless, if the appropriate drug have not been found. Similar to a situation in a battlefield, the drug is the bullet in this pandemic war, and engineering technology such as particle processing and formulation are the weaponry instrument. The bullet and the instrument complement to each other. Once the bullet will have been available, the instrument, accompanied with experts experience in particular within the pulmonary delivery strategy, can be used to refine the attempt to reach its goal. 
Table 2. Short resume of inhalable pharmaceutical study related to the Covid - 19 treatment.

\begin{tabular}{|l|l|l|l|}
\hline $\begin{array}{c}\text { Therapeutic } \\
\text { Agent }\end{array}$ & $\begin{array}{c}\text { System } \\
\text { (Excipient) }\end{array}$ & \multicolumn{1}{|c|}{ Notes } & $\begin{array}{c}\text { Refer- } \\
\text { ence }\end{array}$ \\
\hline $\begin{array}{l}\text { Dexame- } \\
\text { thasone } \\
\text { (corticosteroid) }\end{array}$ & $\begin{array}{l}\text { Large po- } \\
\text { rous particle } \\
\text { (Hyaluronic } \\
\text { acid) }\end{array}$ & $\begin{array}{l}\text { Asthma } \\
\text { treatment } \\
\text { study }\end{array}$ & {$[14]$} \\
\hline $\begin{array}{l}\text { Redemsivir } \\
\text { (antiviral) }\end{array}$ & $\begin{array}{l}\text { Nanolipo- } \\
\text { some }\end{array}$ & $\begin{array}{l}\text { Covid - } \\
19 \text { trat- } \\
\text { ment } \\
\text { study }\end{array}$ & {$[15]$} \\
\hline $\begin{array}{l}\text { Salinomycin } \\
\text { (antibiotic) }\end{array}$ & Nanolipid & $\begin{array}{l}\text { Covid - } \\
19 \text { treat- } \\
\text { ment } \\
\text { study }\end{array}$ & {$[16]$} \\
\hline $\begin{array}{l}\text { Curcumin } \\
\text { (nutraceutical) }\end{array}$ & $\begin{array}{l}\text { Nanoparti- } \\
\text { cles } \\
\text { (review) }\end{array}$ & $\begin{array}{l}\text { Covid - } \\
19 \text { treat- } \\
\text { ment } \\
\text { study }\end{array}$ & {$[17]$} \\
\hline
\end{tabular}

\section{CONCLUSION.}

The spread of the pandemic of the Covid - 19 requires multidisciplinary attempts to confine its destructive effects. From this article, the pulmonary administration might be used as one of many strategies to fight the disease. The pulmonary strategy provides potential to suppress the disease right in its favourite place, yet it is also vital to human life, the pulmonary system. The appropriate pharmaceuticals as candidates are still under investigations. Once the appropriate formula and bioactive agent could be proposed, it can be developed further through inhalable particle engineering strategy to treat patients suffering from this illness.

\section{ACKNOWLEDGMENT}

The spread of the pandemic of the Covid - 19 requires multidisciplinary attempts to confine its destructive effects. From this article, the pulmonary administration might be used as one of many strategies to fight the disease. The pulmonary strategy provides potential to suppress the disease right in its favorite place, yet it is also vital to human life, the pulmonary system. The appropriate pharmaceuticals as candidates are still under investigations. Once the appropriate formula and bioactive agent could be proposed, it can be developed further through inhalable particle engineering strategy to treat patients suffering from this illness.

\section{REFERENCES}

[1] Sun D 2020 Remdesivir for treatment of Covid-19: combination of pulmonary and IV administration may offer aditional benefit, The AAPS 22, 77.
[2] Parisi G F, Carota G, Castracani C C, Spampinato M, Manti S, Papale M, Di Rosa M, Barbagallo I and Leonardi S 2021 Nutraceuticals in the prevention of viral infections, including Covid-19, among the pediatric population: a review of literature, Int. J of Mol Sci 22, 2465.

[3] Sih R 2008 New process development of dense gas technology for the processing of pharmaceuticals, PhD Thesis, UNSW Sydney.

[4] Chaturvedi N and Solanki H 2013 Pulmonary drug delivery system: a review, J of App. Pharm, Vol 5(3).

[5] Labiris M R, Dolovic M B 2003 Pulmonary drug delivery. Part II, Br J Clin. Pharmacology 56.

[6] Kha I, Elhissi A, Shah M, Ahnan M and Ahmed W 2013 Liposome - based carrier systems and devices used for pulomonary drug delivery, Biomaterial and Medical Tribology, Woodhead Pub Ltd.

[7] Sibum I, Hagedorn P, de Boer A, Frijlink H W and Grasmeijer F 2018 Challenges for pulmonary delivery high powder doses, Int. J of Pharmaceutics Vol 546, pp. $325-336$.

[8] Leal R 2017 Inhalation devices: various forms of administration for therapeutic optimization, Open $\mathbf{J}$ of Asthma Vol 1 (1), pp. 037 - 044.

[9] Geller D 2005 Comparing clinical features of the nebulizers, metered dose inhaler and dry powder inhaler, Resp Care Vol 50, p 1313.

[10] Chan H K 2003 Inhalation drug delivery devices and emerging technologies, Expert Opini. Ther. Patents Vol 13 (9), pp. 1333 - 1343.

[11] Hickey A J, Martonen T B and Yang Y 1996 Theoretical relationship of lung deposition to the fine particle fraction of inhalation aerosols Pharm. Acta Helv. 71, 185-190.

[12] Sarasija J 2012 Pulmonary drug delivery strategies: A concise, systematic review, Lung India Vol 29 (1), pp. $44-49$.

[13] Chow A, Tong H, Chattopadhyay P and Shekunov B 2007 Particle engineering for pulmonary drug delivery, Pharm Res Vol 24, p. 1203.

[14] N' Guessan, Fattal E, Chapron D, Guentin C, Koffi A and Tsapis N 2018 Dexamethasone palmitate large porous particles: A controlled release formulation for lung delivery of corticosteroids, Eur. J. Pharm Sci 113, pp. 185 - 192.

[15] Vartak R, Patil S, Saraswat A, Patki M, Kunda M and Patel K 2021 Aerosolized nanoliposomal carrier of remdesivir: an effective alternative for COVID-19 treatment in vitro. Nanomedicine 16 (14), pp. $1187-1202$.

[16] Pindiprolu S, Kumar C, Golla V, Likitha P, Chandra S K, Bacha S K and Ramachandra R K 2020 
Pulmonary delivery of nanostructured lipid carriers for effective repurposing of salinomycin as an antiviral agent, Med. Hypo 143, 109858.

[17] Dourado D, Freire D, Pereira D, Amaral - Machado L, Alencar E, Barros A and Egito E 2021 Will curcumin nanosystems be the next promising antiviral alternatives in COVID-19 treatment trials?, Biomed \& Pharm. Vol 139, 111578. 